\title{
APPLICATION OF VISUALIZATION WITH TECHNICAL MEANS DURING ENDURANCE TRAINING ON TREADMILL AND STATIONARY BICYCLE
}

\author{
Vladimir Angelov \\ National Sports Academy "Vassil Levski", Sofia, Bulgaria
}

\begin{abstract}
The aim of the study is to compare recorded physiological parameters during running and cycling on simulator devices in normal conditions and in conditions of audio-visual background through the help of TV monitor and $3 D$ virtual reality glasses.

Subject of the study is 12 high level Bulgarian acrobats and trampoline gymnasts aged $21 \pm 1.8$ years. All indicators studied were compared to inform about the body's functional status during an aerobic task performance in normal conditions, and in alternative conditions through visualization of running and cycling routes with the help of $2 D$ and $3 D$ videos. The size of the total training load in the two types of conditions is equal.

The collected data was statistically processed. The mean and peak values were analyzed. Statistically significant results on the treadmill were found for the mean values of $\mathrm{VO}_{2}(\mathrm{NC}: 1673 \pm 182 \mathrm{ml} / \mathrm{min}, A C: 1601 \pm 192 \mathrm{ml} / \mathrm{min}$ ), $\mathrm{VO} / 2 \mathrm{~kg}$ (NC: $25 \pm 2.2 \mathrm{ml} / \mathrm{kg} / \mathrm{min}, A C: 24 \pm 2.6 \mathrm{ml} / \mathrm{kg} / \mathrm{min}$ ), $V E / V C O_{2}$ (NC: $28.5 \pm 1.5, A C: 27.5 \pm 1.7$ ), and RER (NC: $0.85 \pm 0.04, A C:$ $0.89 \pm 0.02)$. Statistically significant results of the peak values on the same simulator were found for $\mathrm{VO}_{2}$ (NC: $2375 \pm 327$ $\mathrm{ml} / \mathrm{min}, A C: 2218 \pm 328 \mathrm{ml} / \mathrm{min}$ ), $V O_{2} / \mathrm{kg}$ (NC: $35 \pm 4.5 \mathrm{ml} / \mathrm{kg} / \mathrm{min}, A C: 33 \pm 4 \mathrm{ml} / \mathrm{kg} / \mathrm{min}$ ), HR (NC: $170 \pm 8.9 \mathrm{beats} / \mathrm{min}$,

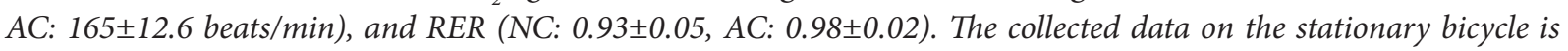
statistically insignificant.

On the basis of the treadmill running results a conclusion for more economic aerobic work during the use of $2 D$ video visualization can be drawn. The results on the stationary bicycle do not allow a general conclusion for the effect of the application of $3 D$ video with VR glasses to be drawn.
\end{abstract}

Key words: indoor training, visualization, physiological indicators

\section{INTRODUCTION}

The basic idea of this development is related to the application of the modern technological advances in sport. The focus is on the aerobic endurance workout using stationary devices in a laboratory condition. Indoors training has its own peculiarities. A major advantage of using simulator devices is the opportunity to perform independent of weather conditions training activities. In addition, stationary simulators allow exercising a greater control over physiological parameters during training work. Fitness devices are a good tool for functional improvement and maintenance of health, but they have limited capabilities (Cui, Wu, 2017). In other studies, reviewed the authors compared the different stationary devices exercise and their effect on certain physiological parameters (Prosser et al., 2011; Kisan et al., 2012; Bouillon et al., 2016). The main disadvantage of endurance workout using treadmill, bicycle ergometer, rowing ergometer and other similar devices is the great monotony. This gave rise to the idea of creating a positive emotional background during exercise work through audio-video visualization using $2 \mathrm{D}$ monitor and $3 \mathrm{D}$ virtual reality glasses.

The use of a music background is widely practiced during aerobic outdoor or indoor fitness activities. In addition to the use of music players, some modern treadmills have screens installed that allow video to be used while running on the device. The review of the information sources revealed that one study examined the influence of motivational and neutral music on endurance and a number of psychophysical indicators during a long-distance walking task on treadmill (Karageorghis et al., 1988). Other studies for the impact of the audio-visual means on the functional status of the athletes during endurance workout on stationary devices have not been found. This fact was a source of additional motivation for carrying out the present development. 
According to the hypothesis of this study, the use of visualization with technical means of running and cycling routes during endurance workout on stationary devices, will increase the positive emotions and efficiency of the training work.

The aim of the study is to compare basic physiological indicators while running and cycling on treadmill and bicycle ergometer under normal conditions and with the help of audio-video background using $2 \mathrm{D}$ monitor and $3 \mathrm{D}$ virtual reality glasses.

\section{METHOD}

Object and participants

The object of this study was the following physiological indicators established during aerobic test on a treadmill and a stationary bicycle: oxygen consumption $\left(\mathrm{VO}_{2}, \mathrm{ml} / \mathrm{min}\right)$, relative oxygen consumption $\left(\mathrm{VO}_{2} / \mathrm{kg}, \mathrm{ml} / \mathrm{kg} / \mathrm{min}\right)$, oxygen pulse $\left(\mathrm{VO}_{2} / \mathrm{HR}\right)$, heart rate $(\mathrm{HR}, \mathrm{bpm})$, ventilatory oxygen equivalent $\left(\mathrm{VE} / \mathrm{VO}_{2}\right)$, ventilator equivalent of carbon dioxide $\left(\mathrm{VE} / \mathrm{VCO}_{2}\right)$, respiratory equivalent (RER), pulmonary ventilation (VE, $1 / \mathrm{min}$ ), respiratory volume $(\mathrm{VT}, \mathrm{l})$ and respiratory rate $(\mathrm{BF}$, breaths per $\mathrm{min}$ ). The indicators were determined using Jäger spiro-ergometric equipment, model "Oxycon Pro". The data collected provide information on the functional status of the athletes.

The study participants were 14 students ( 9 males, 5 females) aged 19-26 years $(21 \pm 1.78)$ from National Sports Academy, Sofia, Bulgaria. All of them were qualified athletes practicing sports acrobatics and trampoline gymnastics. Before the beginning of the functional study, all participants undergo a medical examination. A case history was taken, a physical status has been drawn up, a heart rate and a blood pressure were measured, and an electrocardiogram was made.

\section{Functional testing}

The functional study was accomplished while the athletes performing an aerobic task on a treadmill (T) and a bicycle ergometer (BE). An aerobic workload in a steady state with equivalent intensity and duration in two different types of conditions was used. The study consists of two stages. The first stage was completed within 2 weeks. It included data collection of physiological indicators while running on a treadmill in normal conditions over the first week and in alternative conditions in the second week. The workload under normal con- ditions (NC) is performed without audio-video background, while under the alternative conditions (AC) the use of video surveillance of a mountain running route is included. For visualization purposes, a route was taken using an action camera located on the runner's head. The loading pattern was the same under the both types of study conditions. The duration of the aerobic task was $18 \mathrm{~min} .36 \mathrm{sec}$. The functional test model included three parts of different duration, running speed and slope. The first part had a duration of $8 \mathrm{~min}$, speed $6 \mathrm{~km} / \mathrm{h}$, slope $0^{\circ}$. Second part was with duration $4 \mathrm{~min} 36$ sec, speed $4 \mathrm{~km} / \mathrm{h}$, slope $10^{\circ}$. The third part is final with a duration of $6 \mathrm{~min}$, speed $8 \mathrm{~km} / \mathrm{h}$, slope $0^{\circ}$. The workload model has been tailored to the particularities of the running route used for $2 \mathrm{D}$ video visualization under the alternative conditions. The video background was provided with the help of a laptop positioned in front of the treadmill at the level of athletes' gaze. The size of the workload used in the treadmill functional test was defined on the basis of the sports specialization of the participants.

The second stage of the functional study was conducted for 3 weeks. It involves the data collection during aerobic task performing on a bicycle ergometer. The study was also realized in two types of conditions, normal and alternative. The normal conditions did not include audio-video background, while the alternative conditions involved video viewing of beautiful countryside using $3 \mathrm{D}$ virtual reality glasses. Data collection was performed on a random basis. Some of the participants started the study under normal conditions while the rest of the athletes began it using $3 \mathrm{D}$ virtual reality glasses. The loading pattern was the same under both types of study conditions. The duration of the aerobic task was 17 minutes. A variable aerobic work during cycling was applied by changing the pedaling resistance. The workload model included three parts of different duration and pedaling resistance, but at the same tempo. The resistance was determined individually according to the body weight of the participants. The duration of the starting part was $6 \mathrm{~min} 30 \mathrm{sec}$, resistance $0.8 \mathrm{~W} / \mathrm{kg}$, temp $60 \mathrm{rpm}$. The middle part had a duration of 4 min, resistance $1.6 \mathrm{~W} / \mathrm{kg}$, temp $60 \mathrm{rpm}$. The final part lasted 6 minutes 30 seconds, resistance $1.2 \mathrm{~W} /$ $\mathrm{kg}$, temp $60 \mathrm{rpm}$.

\section{Statistical methods}


The data collected from the conducted studies were statistically processed and analyzed with the statistics package SPSS 17.0. The data were descriptively analyzed (mean \pm standard deviation). Student's paired t-test for normal data distribution to find the difference in the variables studied was used. The level of significance $\mathrm{p} \leq 0.05$ was adopted in all cases.

\section{RESULTS}

On the basis of the medical examination results the conclusion that the participants can be admitted to the conduction of the functional study was drawn. The results of each participant from the study on the both stationary devices under the both types of conditions were statistically processed via descriptive analysis. Two sets of data were systematized. First group included the average values of the studied indicators of each participant. Second group involved the peak values of each participant's indicators. These two categories of data were subjected to new descriptive analysis. Table 1 shows the results of the treadmill study while Table 2 illustrates the results of the stationary bicycle. Each table summarizes the data obtained and their statistical significance under the two types of conditions of the functional study on the respective stationary simulator.

Table 1. Results of the descriptive analysis of the average and peak values of the parameters from the treadmill study.

\begin{tabular}{|c|c|c|c|c|c|c|}
\hline $\begin{array}{l}\text { Parameters } \\
\text { (Treadmill) }\end{array}$ & $\begin{array}{c}\text { Normal } \\
\text { conditions } \\
\text { (Average) }\end{array}$ & $\begin{array}{l}\text { Alternative } \\
\text { conditions } \\
\text { (Average) }\end{array}$ & $\begin{array}{c}p \text {-values } \\
\text { (p } \leq 0.05 \text { ) } \\
\text { (Average) }\end{array}$ & $\begin{array}{c}\text { Normal } \\
\text { conditions } \\
\text { (Peak) }\end{array}$ & $\begin{array}{c}\text { Alternative } \\
\text { conditions } \\
\text { (Peak) }\end{array}$ & $\begin{array}{c}\text { p-values } \\
\text { (p } \leq 0.05) \\
\text { (Peak) }\end{array}$ \\
\hline $\mathrm{VO}_{2}$ & $1672.9 \pm 181.8$ & $1601.2 \pm 191.6$ & $<0.05$ & & $2218.3 \pm 328.4$ & $<0.05$ \\
\hline $\mathrm{VO}_{2} / \mathbf{k g}$ & $24.6 \pm 2.2$ & $23.6 \pm 2.6$ & $<0.05$ & $35.0 \pm 4.5$ & $32.7 \pm 4.0$ & $<0.05$ \\
\hline $\mathrm{VO}_{2} / \mathrm{HR}$ & $11.7 \pm 1.8$ & $11.7 \pm 2.2$ & $>0.05$ & $14.6 \pm 2.4$ & $13.8 \pm 2.7$ & $>0.05$ \\
\hline HR & $141.8 \pm 9.9$ & $137.8 \pm 16.0$ & $>0.05$ & $170.2 \pm 8.9$ & $165.1 \pm 12.6$ & $<0.05$ \\
\hline $\mathrm{VE} / \mathrm{VO}_{2}$ & $24.1 \pm 1.6$ & $24.5 \pm 1.7$ & $>0.05$ & $28.9 \pm 2.2$ & $29.6 \pm 2.5$ & $>0.05$ \\
\hline $\mathrm{VE} / \mathrm{VCO}_{2}$ & $28.5 \pm 1.5$ & $27.5 \pm 1.7$ & $<0.05$ & $34.2 \pm 2.5$ & $33.3 \pm 3.6$ & $>0.05$ \\
\hline RER & $0.85 \pm 0.4$ & $0.89 \pm 0.02$ & $<0.05$ & $0.93 \pm 0.05$ & $0.98 \pm 0.02$ & $<0.05$ \\
\hline VE & $45.2 \pm 3.5$ & $44.0 \pm 4.1$ & $>0.05$ & $68.4 \pm 7.8$ & $65.1 \pm 10.0$ & $>0.05$ \\
\hline VT & $1.5 \pm 0.3$ & $1.5 \pm 0.3$ & $>0.05$ & $2.0 \pm 0.5$ & $1.9 \pm 0.6$ & $>0.05$ \\
\hline BF & $29.5 \pm 3.8$ & $29.1 \pm 4.0$ & $>0.05$ & $39.9 \pm 2.5$ & $39.7 \pm 4.3$ & $>0.05$ \\
\hline
\end{tabular}

Table 2. Results of the descriptive analysis of the average and peak values of the indicators from the stationary bicycle study.

\begin{tabular}{|c|c|c|c|c|c|c|}
\hline & $\begin{array}{c}\text { Normal } \\
\text { conditions } \\
\text { (Average) }\end{array}$ & $\begin{array}{l}\text { Alternative } \\
\text { conditions } \\
\text { (Average) }\end{array}$ & $\begin{array}{c}\text { p-values } \\
\text { (p } \leq 0.05 \text { ) } \\
\text { (Average) }\end{array}$ & $\begin{array}{c}\text { Normal } \\
\text { conditions } \\
\text { (Peak) }\end{array}$ & $\begin{array}{c}\text { Alternative } \\
\text { conditions } \\
\text { (Peak) }\end{array}$ & $\begin{array}{c}\text { p-values } \\
(\mathbf{p} \leq 0.05) \\
\text { (Peak) }\end{array}$ \\
\hline $\mathrm{VO}_{2}$ & $1218.1 \pm 194.9$ & $1301.8 \pm 313.4$ & $>0.05$ & $1675.8 \pm 312.0$ & $1740.6 \pm 502.8$ & $>0.05$ \\
\hline $\mathrm{VO} / \mathrm{kg}$ & $19.1 \pm 1.3$ & $20.2 \pm 1.7$ & $>0.05$ & $26.2 \pm 2.0$ & $27.0 \pm 3.6$ & $>0.05$ \\
\hline VO $/ \mathrm{HR}$ & $9.6 \pm 2.3$ & $10.1 \pm 2.7$ & $>0.05$ & $11.7 \pm 2.7$ & $12.3 \pm 3.1$ & $>0.05$ \\
\hline HR & $128,4 \pm 13.8$ & $129.7 \pm 13.6$ & $>0.05$ & $148.1 \pm 16.9$ & $151.0 \pm 19.0$ & $>0.05$ \\
\hline $\mathrm{VE} / \mathrm{VO}_{2}$ & $25.7 \pm 2.2$ & $24.7 \pm 2.0$ & $>0.05$ & $29.5 \pm 2.9$ & $28.1 \pm 2.7$ & $>0.05$ \\
\hline $\mathrm{VE} / \mathrm{VCO}_{2}^{2}$ & $29.0 \pm 2.1$ & $27.7 \pm 2.1$ & $>0.05$ & $31.8 \pm 2.3$ & $30.1 \pm 2.7$ & $>0.05$ \\
\hline RER & $0.89 \pm 0.04$ & $0.89 \pm 0.04$ & $>0.05$ & $0.98 \pm 0.04$ & $0.98 \pm 0.06$ & $>0.05$ \\
\hline VE & $35.5 \pm 3.6$ & $36.1 \pm 6.7$ & $>0.05$ & $51.5 \pm 8.1$ & $50.6 \pm 12.0$ & $>0.05$ \\
\hline VT & $1.3 \pm 0.2$ & $1.4 \pm 0.2$ & $>0.05$ & $1.7 \pm 0.4$ & $1.8 \pm 0.4$ & $>0.05$ \\
\hline BF & $27.3 \pm 2.7$ & $26.1 \pm 2.9$ & $>0.05$ & $33.9 \pm 3.0$ & $31.8 \pm 3.8$ & $>0.05$ \\
\hline
\end{tabular}


Statistically significant results on mean values of the treadmill study were established for oxygen consumption, relative oxygen consumption, the ventilator equivalent of carbon dioxide and the respiratory equivalent. The comparison of the peak values from the treadmill study showed statistically significant results for oxygen consumption, relative oxygen consumption, heart rate, and respiratory rate.

In the study of the stationary bicycle no statistically significant results were found for the two categories of values (mean and peak) of the all parameters studied.

The treadmill study showed that the average value of oxygen consumption in standard conditions was $1673 \pm 182 \mathrm{ml} / \mathrm{min}$, and under conditions of video visualization $1601 \pm 192 \mathrm{ml} / \mathrm{min}$. The peak value of oxygen consumption under normal conditions reached $2375 \pm 327 \mathrm{ml} / \mathrm{min}$ and under alternative conditions $2218 \pm 328 \mathrm{ml} / \mathrm{min}$. This trend is confirmed by the established statistically significant results of relative oxygen consumption. The average and peak values established under standard conditions were respectively $25 \pm 2.2 \mathrm{ml} / \mathrm{kg} / \mathrm{min}$ and $35 \pm 4.5 \mathrm{ml} / \mathrm{kg} / \mathrm{min}$. Under conditions of video background use, the mean and peak values registered were $24 \pm 2.6 \mathrm{ml} / \mathrm{kg} / \mathrm{min}$ and $33 \pm 4.0 \mathrm{ml} / \mathrm{kg} /$ min. The stationary bicycle study under normal conditions showed that the average values of $\mathrm{VO}_{2}$ are $1218 \pm 195 \mathrm{ml} / \mathrm{min}$ and of $\mathrm{VO}_{2} / \mathrm{kg} 19 \pm 1.3 \mathrm{ml} /$ $\mathrm{kg} / \mathrm{min}$. The peak values are $1676 \pm 312 \mathrm{ml} / \mathrm{min}$ and $26 \pm 2.0 \mathrm{ml} / \mathrm{kg} / \mathrm{min}$ respectively. These two indicators when using virtual reality glasses have average values of $1302 \pm 313 \mathrm{ml} / \mathrm{min}$ and $20 \pm 1.7 \mathrm{ml} / \mathrm{kg} / \mathrm{min}$. The peak values are $1741 \pm 503 \mathrm{ml} / \mathrm{min}$ and $27 \pm 3.6$ $\mathrm{ml} / \mathrm{kg} / \mathrm{min}$ respectively.

The heart rate results of the treadmill functional study under normal conditions were statistically insignificant. Average values of $142 \pm 9.9 \mathrm{bpm}$ and peak values of $170 \pm 8.9 \mathrm{bpm}$ was found. Statistically significant results under the alternative conditions of video background in the same study were established. Average values of $138 \pm 16.0 \mathrm{bpm}$ and peak values of $165 \pm 12.6 \mathrm{bpm}$ was registered. In the stationary bicycle study lower levels of heart rate in normal conditions with mean value of $128 \pm 13.8$ bpm and peak value of $148 \pm 16.9 \mathrm{bpm}$ was found. An average value of $130 \pm 13.6 \mathrm{bpm}$ and peak value of $151 \pm 19.0 \mathrm{bpm}$ in alternative conditions by using of virtual reality glasses have been registered. It is obvious that the difference of the results in the both types of conditions is small.

All recorded values of the oxygen pulse are statistically insignificant. The data of treadmill study show that the mean values in the two types of conditions are equivalent (NC: $11.7 \pm 1.8$, AC: $11.7 \pm 2.2$ ) and the peak values are similar, with a slightly higher result in normal conditions $(\mathrm{NC}=14.6 \pm 2.4$, $\mathrm{AC}=13.8 \pm 2.7$ ). Functional testing on the bicycle ergometer also found similar results of this indicator in the both types of conditions in the both data categories. A slightly higher values in alternative conditions by using virtual reality glasses were found (mean values: $\mathrm{NC}=9.6 \pm 2.3, \mathrm{AC}=10.1 \pm 2.7$; peak values: $\mathrm{NC}=11.7 \pm 2.7, \mathrm{AC}=12.3 \pm 3.1)$.

The ventilatory oxygen equivalent results are statistically insignificant. Similar values of this parameter in the treadmill functional test under the two types of conditions were registered (mean values: $\mathrm{NC}=24.1 \pm 1.6, \mathrm{AC}=24.5 \pm 1.7$; peak values: $\mathrm{NC}=28.9 \pm 2.2, \mathrm{AC}=29.6 \pm 2.5$ ). To a small extent greater respiratory effort under the alternative conditions by using a video background has been established. Higher values of this indicator in the stationary bicycle study under standard conditions were found (mean values: $\mathrm{NC}=25.7 \pm 2.2, \mathrm{AC}=24.7 \pm 2.0$; peak values: $\mathrm{NC}=29.5 \pm 2.9, \mathrm{AC}=28.1 \pm 2.7$ ).

Statistically significant results for the average values and statistically insignificant for the peak values of ventilator equivalent of carbon dioxide $\left(\mathrm{VE} / \mathrm{VCO}_{2}\right)$ in the treadmill study were found (mean values: $\mathrm{NC}=28.5 \pm 1.5, \mathrm{AC}=27.5 \pm 1.7$; peak values: $\mathrm{NC}=34.2 \pm 2.5, \mathrm{AC}=33.3 \pm 3.6)$. The difference between the results in the two types of conditions is small but in favor of the lower values under alternative conditions. The study on the bicycle ergometer showed the same trend (mean values: $\mathrm{NC}=29.0 \pm 2.1, \mathrm{AC}=27.7 \pm 2.1$; peak values: $\mathrm{NC}=31.8 \pm 2.3, \mathrm{AC}=30.1 \pm 2.7)$.

The respiratory equivalent results of the treadmill study are statistically significant, unlike those on the bicycle ergometer. Comparison of the data from the two types of conditions showed that in the treadmill study under alternative conditions, higher values of the respiratory equivalent were found (mean values: $\mathrm{NC}=0.85 \pm 0.4, \mathrm{AC}=0.89 \pm 0.02$; peak values: $\mathrm{NC}=0.93 \pm 0.05, \mathrm{AC}=0.98 \pm 0.02)$. The study 
on the bicycle ergometer registered equivalent values of this indicator in the two types of conditions (mean value: $\mathrm{NC}=0.89 \pm 0.04, \mathrm{AC}=0.89 \pm 0.04$; peak values: $\mathrm{NC}=0.98 \pm 0.04, \mathrm{AC}=0.98 \pm 0.06$ ).

Maximum pulmonary ventilation (VE) in this study was determined. All results are statistically insignificant. Similar results were reported for the studies of the both stationary simulators in both types of conditions. Higher values in the treadmill study under standard conditions were found (mean values: $\mathrm{NC}=45.2 \pm 3.5, \mathrm{AC}=44.0 \pm 4.1$; peak values: $\mathrm{NC}=68.4 \pm 7.8, \mathrm{AC}=65.1 \pm 10.0)$. The same trend about the peak values of the stationary bicycle test was observed. The proportion in regard to the mean values is inverse (mean values: $\mathrm{NC}=35.5 \pm 3.6$, $\mathrm{AC}=36.1 \pm 6.7$; $\quad$ peak values: $\mathrm{NC}=51.5 \pm 8.1$, $\mathrm{AC}=50.6 \pm 12.0$ ).

The results for the respiratory volume found in this study are statistically insignificant. The reported values for this indicator in the treadmill and stationary bicycle studies under the two types of conditions are either the same or very close ( $\mathrm{T}$, mean values: $\mathrm{NC}=1.5 \pm 0.3, \mathrm{AC}=1.5 \pm 0.3$; peak values: $\mathrm{NC}=2.0 \pm 0.5, \mathrm{AC}=1.9 \pm 0.6$; $\mathrm{BE}$, mean values: $\mathrm{NC}=1.3 \pm 0.2, \mathrm{AC}=1.4 \pm 0.2$; peak values: $\mathrm{NC}=1.7 \pm 0.4, \mathrm{AC}=1.8 \pm 0.4)$.

All respiratory rate results in this study were statistically insignificant. Higher differences of this indicator in the both conditions of the bicycle ergometer study were established, while the differences of the treadmill study were too small ( $\mathrm{T}$, mean values: $\mathrm{NC}=29.5 \pm 3.8, \mathrm{AC}=29.1 \pm 4.0$; peak values: $\mathrm{NC}=39.9 \pm 2.5, \mathrm{AC}=39.7 \pm 4.3 ; \mathrm{BE}$, mean values: $\mathrm{NC}=27.3 \pm 2.7, \mathrm{AC}=26.1 \pm 2.9$; peak values: $\mathrm{AC}=33.9 \pm 3.0, \mathrm{AC}=31.8 \pm 3.8$ ).

\section{DISCUSSION}

The main findings of this study are in regard to proving the more effective aerobic workout on stationary devices under video background use. According to the literature review the oxygen consumption $\left(\mathrm{VO}_{2}\right)$ values at rest are about $250-300$ $\mathrm{ml} / \mathrm{min}$, and at physical load they reach $4-6 \mathrm{l} / \mathrm{min}$ (Gavriiski et al., 1996). This indicator increases as a linear function of intensity (Iliev, 2002). As an indicator of the intensity of the aerobic system metabolism under energy delivery $\mathrm{VO}_{2}$ is determined by the age and gender of the athlete (Boneva, 2018). Maximum intensity workloads are not met in this study and that is why this parameter has not been recorded. Higher values of oxygen consumption and its derivative relative oxygen consumption in the treadmill functional study have been revealed during performance of the aerobic task under normal conditions. It can be concluded that lower oxygen consumption is an expression of more economical work. This means that the use of $2 \mathrm{D}$ visualization during running on a treadmill leads to bigger economy of the body. The results of the stationary bicycle study show that the oxygen consumption and relative oxygen consumption values are higher when using 3D video background with the help of virtual reality glasses. Such result was unexpected. It can be explained by the additional burden on some sensor systems from the use of 3D virtual reality glasses under alternative conditions.

Another parameter studied is heart rate, which is an integral indicator of the body's function at rest and during exercise. It can be measured in laboratory and field conditions. The heart rate is determined by the magnitude of energy requirements for physical activity, respiratory function, blood oxygen capacity and the degree of oxygen absorption by muscle cells (Iliev, 2002). In addition, the heart rate is directly related to the minute and stroke volume of the heart. There is a linear relationship between this indicator and oxygen consumption. A useful approach for the theory and the practice is to compare the change in different physiological parameters at the same heart rate (Somlev, 2015; Andersen, Saltin, 1985). The comparative analysis of the heart rate data from the treadmill study leads to the conclusion that the performance of the aerobic task on a treadmill in alternative conditions was accomplished at the expense of a more economical work of the cardiovascular system. The results of this parameter during the bicycle ergometer functional test indicate that there is an inverse relationship with the heart rate values on the treadmill. The lack of statistical significance of the heart rate results does not allow drawing firm conclusions about the impact of the two types of conditions on the economical cardiac work during aerobic workout on a stationary bicycle.

Oxygen pulse $\left(\mathrm{VO}_{2} / \mathrm{HR}\right)$ is an indicator which is a derivative of oxygen consumption and heart rate while the ventilatory oxygen equivalent $\left(\mathrm{VE} / \mathrm{VO}_{2}\right)$ reflects the respiratory effort to achieve a certain oxygen consumption and indicates the breathing 
efficiency. According to some studies, at stepped load, its level reaches over 30 (Piriova, 2000). The oxygen pulse and ventilatory oxygen equivalent results about the impact of the two types of conditions in the treadmill and stationary bicycle studies do not allow a firm generalization to be drawn.

In this study, the ventilator equivalent of carbon dioxide $\left(\mathrm{VE} / \mathrm{VCO}_{2}\right)$ was established as a parameter reflecting the compliance of ventilation and perfusion. The standard for this indicator is $\mathrm{VE} / \mathrm{VCO}_{2}<$ 30 . The peak values recorded at the treadmill study are greater than the pointed-out norm and at the bicycle ergometer they are close to it.

The respiratory equivalent (RER) is an indicator that reflects the relationship between carbon dioxide emissions and oxygen consumption. According to a number of studies, the values of this indicator at rest are $0.70-0.75$, in the zone of transition to limited adaptation are 0.85 , and at maximum load are 1.10-1.30 (Hollmann, Hettinger, 1980). The conducted functional study proved that the aerobic work on the treadmill and stationary bicycle in the both types of conditions is in the zone of transition to limited adaptation. This is evidenced by the average and peak values of the respiratory equivalent established. The findings in this study indicate that the performance of the aerobic task on a treadmill in alternative conditions by video background has resulted in greater carbon dioxide evolution and is closer to the upper boundary of the transition to restricted adaptation.

Pulmonary ventilation is carried out by the respiratory system and occurs in two phases: inhalation and exhalation. The amount of air that is inhaled and exhaled for 1 minute determines the minute volume of respiration. It is known that this indicator is a product of the depth of breathing and its frequency. The lack of statistical significance of the results for maximal pulmonary ventilation in this study does not allow us to make definite conclusions about the degree of impact of the two types of conditions on this parameter.

The respiratory volume (VT) is an indicator that reflects the volume of the gas inhaled or exhaled during each respiratory cycle. According to some studies, when breathing at rest, VT in adults is about $500 \mathrm{ml}$ (Pirova, 2000). Approximately 150 $\mathrm{ml}$ of this volume fills the conductive airways and does not participate in the gas exchange. For alveo- lar ventilation (VA) the staid volume is $350 \mathrm{ml}$. According to other studies, the amount of air involved in alveolar ventilation is $150 \mathrm{ml}$ (Shephard, 1967). The respiratory volume results established in the study are statistically insignificant and give no reason taking them into account when drawing general conclusions about the effect of the two compared conditions.

The last indicator studied is respiratory rate (BF). According to the literature sources reviewed, the ordinary person breathes at rest by an average speed of 16-20 times per minute, while the speed of welltrained athlete is 10-14 times per minute (Piriova, 2000). Respiratory depth is about 0.51 (VT). The physical activity requires bigger respiratory ventilation to meet the body's increased oxygen demand. This can be done in several ways. The most effective option is to find the optimal ratio between the frequency and depth of breathing. In most cases it concerns a frequency of 30-40 breaths per minute, which allows the depth to increase significantly up to $60-70 \%$ of vital capacity (3.6-4,2 1). In general, high respiratory rate is indicative of the lower functionality of respiratory system. With good functional state, the ratio of respiratory rate to heart rate at rest is $1: 4$, and after physical activity $1: 5$ or 1:6. The values of this indicator in the two types of study conditions on the treadmill are similar and fall within the commented norms.

The implementation of this functional study is limited by factors such as age, qualification, sports specialization, number of participants, intensity of workload, indicators for assessing the impact of the two types of study conditions. In future developments, the research scope of this thematic area can be extended by using maximum intensity of exercise and the inclusion of additional psychological tests to assess the emotional state of participants.

\section{CONCLUSION}

The results established of the treadmill functional study make it possible to conclude that under the same size of workload the participants more economically perform the aerobic task under alternative conditions by using $2 \mathrm{D}$ video background.

The study conducted on the bicycle ergometer shows that the application of $3 \mathrm{D}$ visualization using virtual reality glasses during aerobic work did not help to increase efficiency of the motor task per- 
forming. The established results are not statistically significant, so no general conclusion can be drawn about the virtual reality impact on the efficiency of the workout on a stationary bicycle.

\section{REFERENCE}

Andersen, P., Saltin, B. (1985). Maximal perfusion of skeletal muscle in man. Journal of Physiology, 366, pp. 233-249.

Bonova, I. (2018). Vazrastovi osobenosti v razvitieto na dvigatelnoto kachestvo izdrajlivost pri podrastvashti lekoatleti. Sport I nauka, izvanreden broi 1. //Бонова, И. (2018). Възрастови особености в развитието на двигателното качество издръжливост при подрастващи лекоатлети. Спорт и наука, извънреден брой 1. Bouillon, L. et al. (2016). Comparison of trunk and lower extremity muscle activity among four stationary equipment devices: upright bike, recumbent bike, treadmill, and elliptigo. Int J Sports Phys Ther, 11(2): 190-200. Cui, J., Wu, Y. (2017). Design of Control System of Physical Fitness Treadmill Based on Embedded Technology. International Conference on Computer Network, Electronic and Automation (ICCNEA).

Gavriiski, V. i dr. (1996). Fiziologia na choveka. Uchebnik. NSA, Sofia. //Гаврийски, В. и др. (1996). Физиология на човека. Учебник. НСА, София.

Hollmann W., Hettinger Th. (1980). Sportmedizin-Arbeis-und Trainingsgrundlagen.
Iliev, I. (2002). Izdrajlivostta v sporta. Tip-top print, Sofia. //Илиев, И. (2002). Издръжливостта в спорта. Тип-топ принт, София.

Karageorghis, et al. (1988). Psychophysical and Ergogenic Effects of Synchronous Music during Treadmill Walking. Journal of sport and exercise psychology, 31:1, 18-36.

Kisan, R. et al. (2012). Treadmill and Bicycle Ergometer Exercise: Cardiovascular Response comparison. Global Journal of Medical research, 12:5.

Piriova, B. (2000). Fiziologia na choveka. MI ARSO. // Пирьова, Б. (2000). Физиология на човека. МИ "APCO".

Prosser, L.A. et al. (2011). Comparison of elliptical training, stationary cycling, treadmill walking and over ground walking. Gait Posture, 33(2): 244-250.

Shephard, R.J. (1967). Maximum sustained voluntary ventilation in exercise. Clin. Sci., 32, 167.

Smolev, P. (2015). Adaptacionni promeni v sardechnata chestota pri sportisti. NSA Pres, Sofia. //Сомлев, П. (2015). Адаптачионни промени в сәрдечната честота при спортисти. НСА Прес, София.

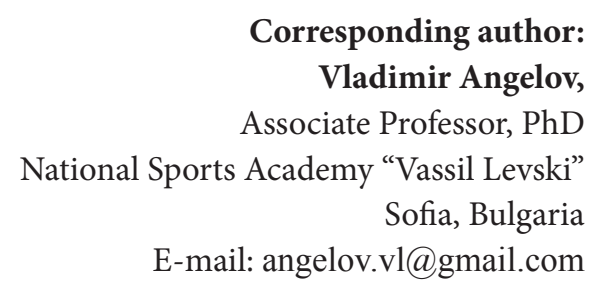

\section{Corresponding author:} Vladimir Angelov,

Associate Professor, $\mathrm{PhD}$ Sofia, Bulgaria E-mail: angelov.vl@gmail.com 